Abstracta Iranica

Revue bibliographique pour le domaine irano-aryen

Volume 32-33 | 2013

Comptes rendus des publications de 2009-2010

\title{
Franklin Lewis. The Semiotic Horizons of Dawn in the Poetry of Hâafiz
}

Anna Livia Beelaert

\section{OpenEdition}

1 Journals

Édition électronique

URL : http://journals.openedition.org/abstractairanica/40961

DOI : 10.4000/abstractairanica.40961

ISSN : 1961-960X

\section{Éditeur :}

CNRS (UMR 7528 Mondes iraniens et indiens), Éditions de l'IFRI

\section{Édition imprimée}

Date de publication : 1 décembre 2013

ISSN : 0240-8910

\section{Référence électronique}

Anna Livia Beelaert, "Franklin Lewis. The Semiotic Horizons of Dawn in the Poetry of Hāfiz », Abstracta Iranica [En ligne], Volume 32-33 | 2013, document 428, mis en ligne le 01 juillet 2016, consulté le 03 octobre 2020. URL : http://journals.openedition.org/abstractairanica/40961 ; DOI : https://doi.org/10.4000/abstractairanica.40961

Ce document a été généré automatiquement le 3 octobre 2020.

Tous droits réservés 
Franklin Lewis. The Semiotic Horizons of Dawn in the Poetry of Hāfiẓ

Anna Livia Beelaert 


\section{RÉFÉRENCE}

Franklin Lewis. « The Semiotic Horizons of Dawn in the Poetry of Ḥăfiz », in : Leonard Lewisohn, ed., Hafiz and The Religion of Love in Classical Persian Poetry. London/New York, I.B. Tauris in association with Iran Heritage Foundation, 2010, p. 251-77.

L'A. a comme point de départ le genre de "l'aube" (alba) comme présenté dans le volume bien connu édité en 1965 par Arthur Hatto, Eos: An Inquiry into the Themes of Lovers' Meetings and Partings at Dawn in Poetry. l'A. montre que si ce genre, ainsi que son double le "contra-alba" (où le poète se plaint à l'aube de n'avoir pas eu de rendez-vous galant la nuit précédente) existe dans la littérature persane classique - il donne quelques exemples tirés des Dìvāns de Sanā'î et Sa'dī - on n'en trouve pas dans le Dìvān de Ḥāfez. Par contre, sa recherche qui consiste en "l'isolement des horizons sémantiques de l'aube comme topique", et qui doit montrer "la relation entre certains thèmes et topiques" chez Ḥăfez (p. 266), s'avère fructueuse. L'A. explore son lexique de l'aube, ç'est-à-dire les différents mots pour l'aube ou le lever du soleil (sahar, șubh, bāmdād, pagāh, sepīda-dam, țulū', șabāḥ) ainsi que les termes qui s'y rapportent comme bulbul et 'andalīb pour le rosssignol; șabūh pour la libation du matin; șabā et nasim pour la brise du matin (qui est parfois représentée comme "messager", barìd ou payk, qui porte une message, payām). Plusieurs fois Ḥâfez laisse voir explicitement les “dimensions religieuses et spirituelles' de l'aube (p. 273), et l'A. réussit à mettre en évidence la "valeur sacrée de l'aube, le moment de grâce, en réponse à la supplication et la souffrance de la nuit de la séparation et de la liminalité" (p. 276). Article exemplaire.

\section{AUTEURS}

\section{ANNA LIVIA BEELAERT}

Université libre de Bruxelles 